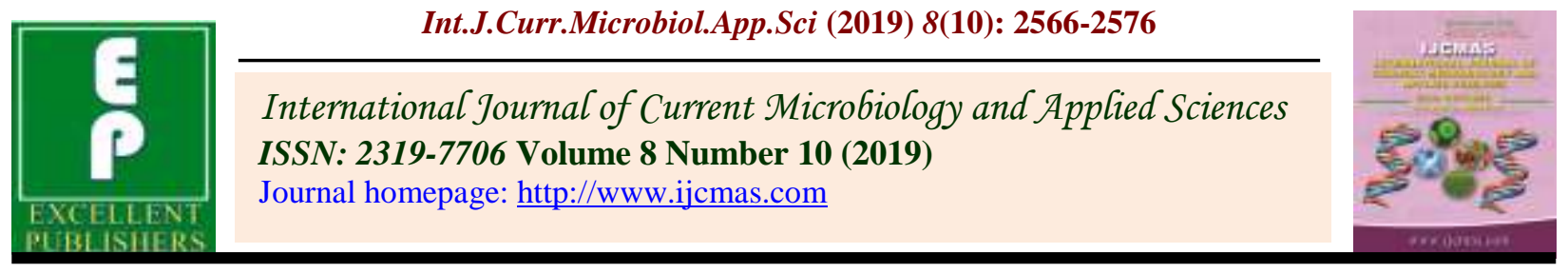

Original Research Article https://doi.org/10.20546/ijcmas.2019.810.297

\title{
Effect of Various Mulches and Irrigation Levels on Root Zone Temperature, Growth and Fruit Yield of Watermelon (Citrullus lanatus T.) cv. Kiran
}

\author{
P.S. Pawar ${ }^{1}$, A.S. Kadale ${ }^{1}$ and G.D. Gadade ${ }^{2}$ \\ ${ }^{1}$ College of Agricultural Engineering and Technology, VNMKV, \\ Parbhani-431402 (M.S.), India \\ ${ }^{2}$ AIRCP on Irrigation Water Management, VNMKV, Parbhani-431402 (M.S.), India \\ *Corresponding author
}

\section{A B S T R A C T}

The field experiment was conducted on watermelon (Citrullus lanatus Thunb) cv. Kiran in

\section{Keywords}

Mulching, Plastic

Mulch, Root zone temperature, Straw mulch, Watermelon

Article Info

Accepted:

18 September 2019

Available Online:

10 October 2019 summer season for two consecutive years viz., 2015 and 2016 at Vasantrao Naik Marathwada Krishi Vidyapeeth, Parbhani. The objective of this study was to determine the effect of different mulches (black plastic mulch, transparent plastic mulch, soybean strawmulch and control)on root zone temperature, growth and fruit yield characters of watermelon under different irrigation levels. Among the mulches soil temperature in transparent and black plastic mulch applications were higher $\left(2.5-5.3{ }^{\circ} \mathrm{C}\right.$ and $2.2-3.0{ }^{0} \mathrm{C}$ respectively) than control. In case of soybean straw mulch, lower mean soil temperature was recorded on an average $0.6{ }^{0} \mathrm{C}\left(0.3-1.2{ }^{0} \mathrm{C}\right)$ than control during both the years of experimentation. Among all mulching treatments, black plastic mulch resulted higher number of branches per vine (10.05), main vine length $(209.16 \mathrm{~cm})$, vine diameter $(8.27$ $\mathrm{mm}$ ) and number of leaves per vine (290.50). Yield of watermelon in black plastic mulch was $28.90 \mathrm{t} / \mathrm{ha}$, which was higher as compare to other mulch and no mulch. There was found significant positive correlation between yield of watermelon and average root zone temperature $\left(\mathrm{R}^{2}=0.708\right)$.

\section{Introduction}

Watermelon (Citrullus lanatus) is an important vegetable crop of the world belonging to the family of Cucurbitaceae. In India it is grown over an area of 81 thousand hectare with total production of about 1789.0 thousand metric tons with average productivity of 22.08 tons per hectare. In Maharashtra it is grown over an area of 660 hectare with average yield in the range of $25-$
30 tons per hectare. Cucurbits share about 5.6 per cent of the total vegetables production of India (Directorate of Economics and Statistics, 2012).

The practice of applying mulches to soil is possibly as old as agriculture itself. Mulches are either organic (derived from plant and animal materials) or inorganic (plastic film). Mulching is a beneficial practice for crop production. Organic mulches properly utilized 
can perform all the benefits of any mulch with possible exception of early season soil warming. Reduced soil temperature is one of the major environmental effects of organic mulches (Schmidt and Worthington, 1998). The use of plastic mulch in agriculture has increased dramatically in the last 10 years throughout the world. This increase is due to benefits such as increase in soil temperature, reduced weed pressure, moisture conservation, reduction of certain insect pests, higher crop yields, and more efficient use of soil nutrients (Subrahmaniyan and Ngouajio, 2012 and Bhanukar et al., 2015). Most commonly used agricultural mulch is black plastic because it prevents weed growth and warms the soil. Clear plastic mulch is also used in some areas due to its increased soil warming characteristics. Black and clear mulches have shown the greatest soil warming potential among the various mulch colors (Ham et al., 1993).

The majority of reports shown that increased root-zone temperature is one of the main benefit associated with the use of plastic mulches. Additional studies also show that, depending on the crop species, geographical region, or time of the year, plastic mulches create high zone-temperature conditions that may be deleterious to growth and yield of vegetables (Diaz-Perez and Batal, 2002; Ibarra-Jimenez et al., 2008; Lamont, 2005)

.The increased root-zone temperature is responsible for rapid initial plant growth and high yield of watermelon as compared to control (Romic et al., 2003; Ban et al., 2009).

However, information concerning the production of watermelon grown on different mulches in Marathwada region of Maharashtra is lacking. Keeping this fact in view, the study was conducted to determine the effects of various mulches on soil temperatures and to evaluate the growth and yield response of watermelon grown on various mulches under drip irrigation system.

\section{Materials and Methods}

\section{Experimental site and treatment details}

The field experiment was conducted in summer season during two consecutive years viz., 2015 and 2016 at research farm of All India Co-ordinated Research Project on Irrigation Water Management, Vasantrao Naik Marathwada Krishi Vidyapeeth, Parbhani. The soil is clayey in texture and slightly alkaline in reaction. The field experiment was laid out in split plot design, wherein main plots were assigned to three irrigation levels based on daily pan evaporation data $\left(\mathrm{I}_{1}-\right.$ drip irrigation at $60 \%$ of pan evaporation, $\mathrm{I}_{2}$ - drip irrigation at $80 \%$ of pan evaporation and $\mathrm{I}_{3}$ - drip irrigation at $100 \%$ of pan evaporation) and sub plots to four mulches BPM - Black polythene mulch $(30 \mu)$, TPM - Transparent polythene mulch (30 $\mu)$, SSM - Soybean straw mulch (5 tonns/ha) and C - Control (without mulch). Thus, the experiment consisted of total 12 treatment combinations which were replicated thrice. All sub plot treatments were randomized in each main plot treatment. Each main treatment plot had three rows of crops with 20 plants in each sub plot. Single seed of cv. Kiran was dibbled at each hill at $2 \mathrm{~m} \mathrm{X}$ $0.5 \mathrm{~m}$ on $1^{\text {st }}$ February, in both years. Irrigation was scheduled as per the treatment and each day's water was applied through drip irrigation, except for days when the crop received more water through rain than was lost through evaporation.

\section{Measurement of soil temperature}

Soil temperature $\left({ }^{0} \mathrm{C}\right)$ was measured at centre of each treatment plot between two plants with three replications by using digital soil thermometer (LCD multi-stem thermometer 
with accuracy $+/-1{ }^{0} \mathrm{C}$ between - 50 to 200 $\left.{ }^{0} \mathrm{C}\right)$ at $5,10,15,20 \mathrm{~cm}$ depth by inserting sensor rod of digital thermometer. The daily temperature of soil was recorded in each plot between 8:00 a.m. and 2:00 p.m. from $21^{\text {st }}$ February to $30^{\text {th }}$ April during both the years of experimentation.

\section{Growth and yield parameters}

For recording growth attributing characters, five representative hills from each net plot were selected randomly. The selected hills were labeled with proper notations and all the growth observations were recorded from these plants. The length of the vine was measured in $\mathrm{cm}$ from base of the plant up to the terminal bud of the main vine. The observations of vine length were recorded at harvest. Data on number of leaves were recorded from five plants of each treatment plots at harvest. The numbers of primary branches arising from the main shoot of the vine were counted as number of branches per vine.

The vine diameter was measured with the help of digital Vernier caliper at harvest. The length and breadth of five randomly selected fruits from each replication was measured in centimeter with a measuring rule at harvest. The volume of watermelons from each replication was used for measuring volume using the water displacement method. Each watermelon was submerged in a container full of water. The volume of the displaced water was measured using a $500 \mathrm{ml}$ capacity cylinder. The fruits weights of five representative plants were recorded for each replication and average weight of fruit per vine were determined. The total number of watermelons and their weight were determined for each net plot and plot wise yield of watermelon was then converted into ton per hectare.

\section{Data analysis}

The observations on soil temperature, growth and yield parameters were subjected to statistical analysis of variance technique as described by Gomez and Gomez, 1984.

\section{Results and Discussion}

\section{Effect on soil temperature}

Pooled soil temperature data was significantly influenced by irrigation levels and mulches (Table 1). The significantly higher soil temperature was recorded under irrigation level 1.0 PE (29.48, 28.95, 28.75 and 28.69 ${ }^{0} \mathrm{C}$ ) at soil depths $5,10,15$ and $20 \mathrm{~cm}$ respectively. These results are in accordance with the results of Chawla et al., (2009) who observed that soil temperature at $15 \mathrm{~cm}$ depth under various mulches were high at irrigation level 1.0 IW/CPE as compared to 0.6 and 0.8 IW/CPE irrigation levels. In case of mulches, the highest daily mean soil temperatures were recorded $31.99,31.34,30.93$ and $30.76{ }^{\circ} \mathrm{C}$ under transparent polythene mulch at soil depths 5, 10, 15 and $20 \mathrm{~cm}$ respectively. This might be due to high transmission of incoming shortwave solar radiation through transparent polythene mulch as compared to other mulches and also the condensed water droplets under surface of mulch which blocked the outgoing long wave infrared radiation. Due to this, transparent polythene mulch retained more heat and which is responsible for higher soil temperature under transparent polythene mulch as compared to other mulches. According to Ham et al., (1993) the clear plastic mulch absorbs little solar radiation but transmits $85 \%$ to $95 \%$ of incoming solar radiation. The lowest daily mean soil temperatures at corresponding depths were $27.03,26.84,26.79$ and $26.86{ }^{\circ} \mathrm{C}$ observed under soybean straw mulch treatment. According to Khan et al., (2013), the vegetative mulches suppressed the soil 
temperature and did not allow the radiant energy to contact the soil directly and emitted back the energy to the atmosphere. Awasthi et al., (2006) reported that soil mulched with organic mulches showed beneficial effect in lowering the soil temperature during summer months, while increase in soil temperature was recorded during the peak winter months. In particular, the amplitude of the soil temperatures decreased with depth. The season effect on soil temperature was found significant. During summer season in 2016 recorded significantly higher soil temperature as compared to summer season in 2015. The interaction effect of season $\mathrm{x}$ mulches and season $\mathrm{x}$ irrigation levels on soil temperature at different depths were found significant, where as interaction effect of irrigation levels $\mathrm{x}$ mulches and season $\mathrm{x}$ irrigation levels $\mathrm{x}$ mulches were found inconsistent with soil depths. Similar results have been earlier reported polythene and organic mulches used in cucumber (Aniekwe and Anike, 2015), groundnut (Khan et al., 2013), capsicum (Sharma and Meshram, 2015; bottle guard (Deshmukh et al., 2013) and in sunflower (Domber et al., 2009).

\section{Effect on growth and yield}

Data on effect of different treatments on growth and yield attributing characters of watermelon are presented in Table 2. It was observed that the application of irrigation at different levels showed the significant differences between growth and yield attributing characters. The application of irrigation water at level 1.0 $\mathrm{PE}\left(\mathrm{I}_{3}\right)$ recorded significantly higher growth and yield attributing characters over the irrigation level 0.6 PE $\left(\mathrm{I}_{1}\right)$, however it was found at par with irrigation level at 0.8 PE. It was observed that, the application of irrigation water at level 1.0 $\mathrm{PE}\left(\mathrm{I}_{3}\right)$ recorded significantly maximum vine length $(212.97 \mathrm{~cm})$, number of branches (8.47), vine diameter $(7.80 \mathrm{~mm})$ and number of leaves at harvest (299.13) over the irrigation level $0.6 \mathrm{PE}\left(\mathrm{I}_{1}\right)$, however it was found at par with irrigation level at $0.8 \mathrm{PE}$ during both the year of experimentations. Similarly, it was observed that, the application of irrigation water at level 1.0 PE $\left(\mathrm{I}_{3}\right)$ recorded significantly maximum average fruit weight $(1.89 \mathrm{~kg})$, fruit length $(22.90 \mathrm{~cm})$, fruit width $(13.66 \mathrm{~cm})$, fruit volume $(2.06$ litre), number of fruits per plot (27.94)and yield (26.62 t/ha) over the irrigation level 0.6 PE $\left(\mathrm{I}_{1}\right)$, however it was found at par with irrigation level at $0.8 \mathrm{PE}$ during both the year of experimentations. There was linear yield increase with increase in the amount of water applied. Several researchers observed yield increase with drip irrigation due to better fruit retention and reduced fruit drop. Similar results were found by Özmen et al., (2015) in watermelon, Ertek et al., (2006) in cucumber and Bhanukar et al., (2015) in Kinnow.

The effect of mulches on growth parameters revealed that different types of mulching materials significantly influenced the growth parameters of watermelon viz., main vine length at harvest, number of branches per vine, vine diameter and number of leaves per vine at harvest over control. Among different mulching treatments, treatment black polythene mulch recorded significantly maximum main vine length $(209.16 \mathrm{~cm})$, number of branches (10.05), vine diameter $(8.27 \mathrm{~mm})$ and number of leaves per vine (290.50)as compared soybean straw mulch and control, but found at par with transparent polythene mulch during both the year. However control recorded the minimum growth.

Similarly, yield attributing data recorded under different mulches indicated that black polythene mulch recorded significantly maximum average fruit weight $(1.99 \mathrm{~kg})$, fruit length $(23.45 \mathrm{~cm})$, fruit width $(14.13 \mathrm{~cm})$, fruit volume (2.17 litre), number of fruits per 
plot (29.02) and yield (28.90 t/ha) which was followed by transparent polythene mulch and soybean straw mulch respectively during two years of experimentation. The increase in growth and yield parameters was attributed to sufficient soil moisture near root zone and minimized the evaporation loss due to mulching. The extended retention of moisture and availability of moisture also leading to higher uptake of nutrient for proper growth and development of plants, resulted higher growth and yield of plant, as compared to control.
Mulching significantly promoted vegetative growth over the non-mulching treatment. The above results are in agreement with Aniekwe and Anike (2015) who reported that, the mulched plots produced plants with greater number of vines, number of leaves, leaf area and vine length of cucumber. Similar kind of observations with respect to plant growth parameters were also reported by Singh and Kamal (2012) in tomato, Mahadeen (2014) in summer vegetables (okra and squash) and in potato (Kumar et al., 2015).

Table.1 Pooled analysis of daily mean soil temperature

\begin{tabular}{|l|c|c|c|c|}
\hline \multirow{2}{*}{\multicolumn{1}{|c|}{ Treatment }} & \multicolumn{4}{|c|}{ Pooled seasonal daily mean soil temperature, ${ }^{\mathbf{0}} \mathbf{C}$} \\
\cline { 2 - 5 } & $\mathbf{5} \mathbf{~ c m}$ & $\mathbf{1 0} \mathbf{~ c m}$ & $\mathbf{1 5} \mathbf{~ c m}$ & $\mathbf{2 0} \mathbf{~ c m}$ \\
\hline Season & & & & \\
\hline $\mathbf{2 0 1 5}$ & $28.56^{\mathrm{b}}$ & $28.06^{\mathrm{b}}$ & $27.86^{\mathrm{b}}$ & $27.75^{\mathrm{b}}$ \\
\hline $\mathbf{2 0 1 6}$ & $30.34^{\mathrm{a}}$ & $29.79^{\mathrm{a}}$ & $29.60^{\mathrm{a}}$ & $29.56^{\mathrm{a}}$ \\
\hline Irrigation levels & & & & \\
\hline $\mathbf{I}_{\mathbf{1}}=\mathbf{0 . 6}$ PE & $29.44^{\mathrm{b}}$ & $28.91^{\mathrm{c}}$ & $28.71^{\mathrm{b}}$ & $28.63^{\mathrm{b}}$ \\
\hline $\mathbf{I}_{\mathbf{2}}=\mathbf{0 . 8}$ PE & $29.44^{\mathrm{b}}$ & $28.93^{\mathrm{b}}$ & $28.72^{\mathrm{b}}$ & $28.64^{\mathrm{b}}$ \\
\hline $\mathbf{I}_{\mathbf{3}}=\mathbf{1 . 0}$ PE & $29.48^{\mathrm{a}}$ & $28.95^{\mathrm{a}}$ & $28.75^{\mathrm{a}}$ & $28.69^{\mathrm{a}}$ \\
\hline Mulches & & & & \\
\hline BPM & $30.49^{\mathrm{b}}$ & $30.04^{\mathrm{b}}$ & $29.96^{\mathrm{b}}$ & $29.86^{\mathrm{b}}$ \\
\hline TPM & $31.99^{\mathrm{a}}$ & $31.34^{\mathrm{a}}$ & $30.93^{\mathrm{a}}$ & $30.76^{\mathrm{a}}$ \\
\hline SSM & $27.03^{\mathrm{d}}$ & $26.84^{\mathrm{d}}$ & $26.79^{\mathrm{d}}$ & $26.86^{\mathrm{d}}$ \\
\hline Control & $28.29^{\mathrm{c}}$ & $27.49^{\mathrm{c}}$ & $27.24^{\mathrm{c}}$ & $27.15^{\mathrm{c}}$ \\
\hline & & Significance & $(p-v a l u e$ \\
\hline Season & 0.001 & 0.001 & 0.001 & \\
\hline I & 0.001 & 0.001 & 0.001 & 0.001 \\
\hline M & 0.001 & 0.001 & 0.001 & 0.001 \\
\hline I x M & $0.46^{\mathrm{NS}}$ & 0.01 & 0.01 & 0.01 \\
\hline Season x I & 0.001 & 0.001 & 0.001 & 0.001 \\
\hline Season x M & 0.001 & 0.001 & 0.001 & 0.001 \\
\hline Season x I x M & $0.85^{\mathrm{NS}}$ & $0.48^{\mathrm{NS}}$ & $0.09^{\mathrm{NS}}$ & 0.03 \\
\hline
\end{tabular}

Means followed by different letter in column differ significantly at $P<0.05$ (LSD test). 
Table.2 Effect of different irrigation levels and mulches on growth and yield of watermelon cv. Kiran

\begin{tabular}{|c|c|c|c|c|c|c|c|c|c|c|}
\hline Treatment & $\begin{array}{c}\text { Vine } \\
\text { length } \\
\text { at } \\
\text { harvest } \\
\text { (cm) }\end{array}$ & $\begin{array}{c}\text { No. of } \\
\text { branches }\end{array}$ & $\begin{array}{c}\text { Vine } \\
\text { diameter } \\
(\mathbf{m m})\end{array}$ & $\begin{array}{c}\text { No. of } \\
\text { leaves at } \\
\text { harvest } \\
\text { per } \\
\text { vine }\end{array}$ & $\begin{array}{c}\text { Average } \\
\text { fruit } \\
\text { weight } \\
\text { (kg) }\end{array}$ & $\begin{array}{c}\text { Fruit } \\
\text { length } \\
\text { (cm) }\end{array}$ & $\begin{array}{c}\text { Fruit } \\
\text { width } \\
\text { (cm) }\end{array}$ & $\begin{array}{c}\text { Fruit } \\
\text { volume } \\
\text { (litre) }\end{array}$ & $\begin{array}{c}\text { No. of } \\
\text { fruits } \\
\text { per plot } \\
\left(20 \mathrm{~m}^{2}\right)\end{array}$ & $\begin{array}{l}\text { Yield } \\
\text { (t/ha) }\end{array}$ \\
\hline \multicolumn{11}{|l|}{ Season } \\
\hline 2015 & $197.32^{\mathrm{a}}$ & $8.40^{\mathrm{a}}$ & $7.65^{\mathrm{a}}$ & $270.81^{\mathrm{a}}$ & $1.77^{\mathrm{a}}$ & $21.72^{\mathrm{a}}$ & $13.56^{\mathrm{a}}$ & $1.81^{\mathrm{a}}$ & $29.23^{\mathrm{a}}$ & $26.22^{\mathrm{a}}$ \\
\hline 2016 & $193.15^{\mathrm{a}}$ & $8.18^{\mathrm{a}}$ & $7.48^{\mathrm{a}}$ & $263.28^{\mathrm{a}}$ & $1.70^{\mathrm{a}}$ & $20.47^{b}$ & $12.33^{b}$ & $1.76^{b}$ & $24.46^{b}$ & $20.96^{b}$ \\
\hline \multicolumn{11}{|l|}{ Irrigation levels } \\
\hline $\mathrm{I}_{1}=0.6 \mathrm{PE}$ & $168.40^{b}$ & $7.92^{b}$ & $7.23^{b}$ & $218.33^{b}$ & $1.47^{b}$ & $18.32^{b}$ & $12.30^{\mathrm{b}}$ & $1.47^{b}$ & $26.14^{\mathrm{a}}$ & $19.32^{\mathrm{D}}$ \\
\hline$I_{2}=0.8 \mathrm{PE}$ & $204.35^{\mathrm{a}}$ & $8.42^{\mathrm{a}}$ & $7.67^{\mathrm{a}}$ & $283.67^{\mathrm{a}}$ & $1.86^{\mathrm{a}}$ & $22.08^{\mathrm{a}}$ & $12.88^{\mathrm{a}}$ & $1.83^{\mathrm{a}}$ & $26.47^{\mathrm{a}}$ & $24.84^{\mathrm{a}}$ \\
\hline$I_{3}=1.0 \mathrm{PE}$ & $212.97^{\mathrm{a}}$ & $8.47^{\mathrm{a}}$ & $7.80^{\mathrm{a}}$ & $299.13^{\mathrm{a}}$ & $1.89^{\mathrm{a}}$ & $22.90^{\mathrm{a}}$ & $13.66^{\mathrm{a}}$ & $2.06^{\mathrm{a}}$ & $27.94^{\mathrm{a}}$ & $26.62^{\mathrm{a}}$ \\
\hline \multicolumn{11}{|l|}{ Mulches } \\
\hline BPM & $209.16^{\mathrm{a}}$ & $10.05^{\mathrm{a}}$ & $8.27^{\mathrm{a}}$ & $290.50^{\mathrm{a}}$ & $1.99^{\mathrm{a}}$ & $23.45^{\mathrm{a}}$ & $14.13^{\mathrm{a}}$ & $2.17^{\mathrm{a}}$ & $29.02^{\mathrm{a}}$ & $28.90^{\mathrm{a}}$ \\
\hline TPM & $199.80^{\mathrm{a}}$ & $9.69^{\mathrm{a}}$ & $8.01^{\mathrm{a}}$ & $276.56^{\mathrm{a}}$ & $1.85^{\mathrm{a}}$ & $21.72^{\mathrm{ab}}$ & $13.20^{\mathrm{a}}$ & $1.87^{b}$ & $27.69^{b}$ & $25.54^{\mathrm{b}}$ \\
\hline SSM & $201.23^{b}$ & $7.99^{b}$ & $7.68^{b}$ & $279.89^{b}$ & $1.67^{b}$ & $20.89^{\mathrm{ab}}$ & $12.58^{\mathrm{b}}$ & $1.65^{c}$ & $26.74^{\mathrm{c}}$ & $22.27^{c}$ \\
\hline Control & $170.75^{\mathrm{c}}$ & $5.36^{\mathrm{c}}$ & $6.32^{c}$ & $221.23^{c}$ & $1.45^{\mathrm{c}}$ & $18.34^{\mathrm{c}}$ & $11.88^{\mathrm{c}}$ & $1.45^{\mathrm{d}}$ & $23.93^{\mathrm{d}}$ & $17.65^{\mathrm{d}}$ \\
\hline Season & 0.167 & 0.100 & 0.229 & 0.223 & 0.093 & $<0.001$ & $<0.001$ & $<0.001$ & 0.001 & $<0.001$ \\
\hline I & $<0.001$ & 0.008 & 0.003 & $<0.001$ & $<0.001$ & $<0.001$ & 0.009 & $<0.001$ & 0.083 & $<0.001$ \\
\hline M & $<0.001$ & $<0.001$ & $<0.001$ & $<0.001$ & $<0.001$ & $<0.001$ & $<0.001$ & $<0.001$ & $<0.001$ & $<0.001$ \\
\hline Season $x$ M & 0.971 & 0.790 & 0.440 & 0.897 & 0.993 & 0.425 & 0.649 & 0.451 & 0.633 & 0.777 \\
\hline Season $x$ I & 0.997 & 0.938 & 0.964 & 0.987 & 0.947 & 0.556 & 0.260 & 0.759 & 0.705 & 0.910 \\
\hline I $\mathbf{x}$ M & 0.003 & 0.053 & 0.791 & 0.028 & 0.431 & 0.649 & 0.716 & 0.445 & 0.935 & 0.534 \\
\hline Season x I x M & 1.000 & 0.989 & 0.413 & 0.976 & 0.974 & 0.194 & 0.884 & 0.317 & 0.709 & 0.970 \\
\hline
\end{tabular}


Table.3 Optimum soil temperatures for watermelon crop

\begin{tabular}{|l|c|c|}
\hline \multicolumn{1}{|c|}{ Yield attributing characters } & \multicolumn{1}{|c|}{ Relationship } & $\begin{array}{c}\text { Optimum RZT, } \\
\text { 0.C }\end{array}$ \\
\cline { 2 - 3 } & \multicolumn{1}{|c|}{ Morning RZT } \\
\hline Yield & $\mathrm{y}=-1.263 \mathrm{x}^{2}+70.11 \mathrm{x}-943.4$ & 27.75 \\
\hline Average fruit weight & $\mathrm{y}=-0.042 \mathrm{x}^{2}+2.378 \mathrm{x}-31.46$ & 28.30 \\
\hline Number of fruits per vine & $\mathrm{y}=-0.041 \mathrm{x}^{2}+2.307 \mathrm{x}-30.05$ & 28.13 \\
\hline & \multicolumn{1}{|c|}{ Afternoon RZT } \\
\hline Yield & $\mathrm{y}=-0.535 \mathrm{x}^{2}+33.11 \mathrm{x}-482.9$ & 30.94 \\
\hline Average fruit weight & $\mathrm{y}=-0.016 \mathrm{x}^{2}+1.023 \mathrm{x}-14.19$ & 31.96 \\
\hline Number of fruits per vine & $\mathrm{y}=-0.018 \mathrm{x}^{2}+1.133 \mathrm{x}-15.62$ & 31.47 \\
\hline & \multicolumn{1}{|c|}{ Average RZT } & \\
\hline Yield & $\mathrm{y}=-0.773 \mathrm{x}^{2}+45.36 \mathrm{x}-636.3$ & 29.34 \\
\hline Average fruit weight & $\mathrm{y}=-0.024 \mathrm{x}^{2}+1.457 \mathrm{x}-19.80$ & 30.35 \\
\hline Number of fruits per vine & $\mathrm{y}=-0.026 \mathrm{x}^{2}+1.528 \mathrm{x}-20.5$ & 29.38 \\
\hline
\end{tabular}

Fig.1 Relation of mean root zone temperature with total yield, average weight of watermelon and number of fruit per vine
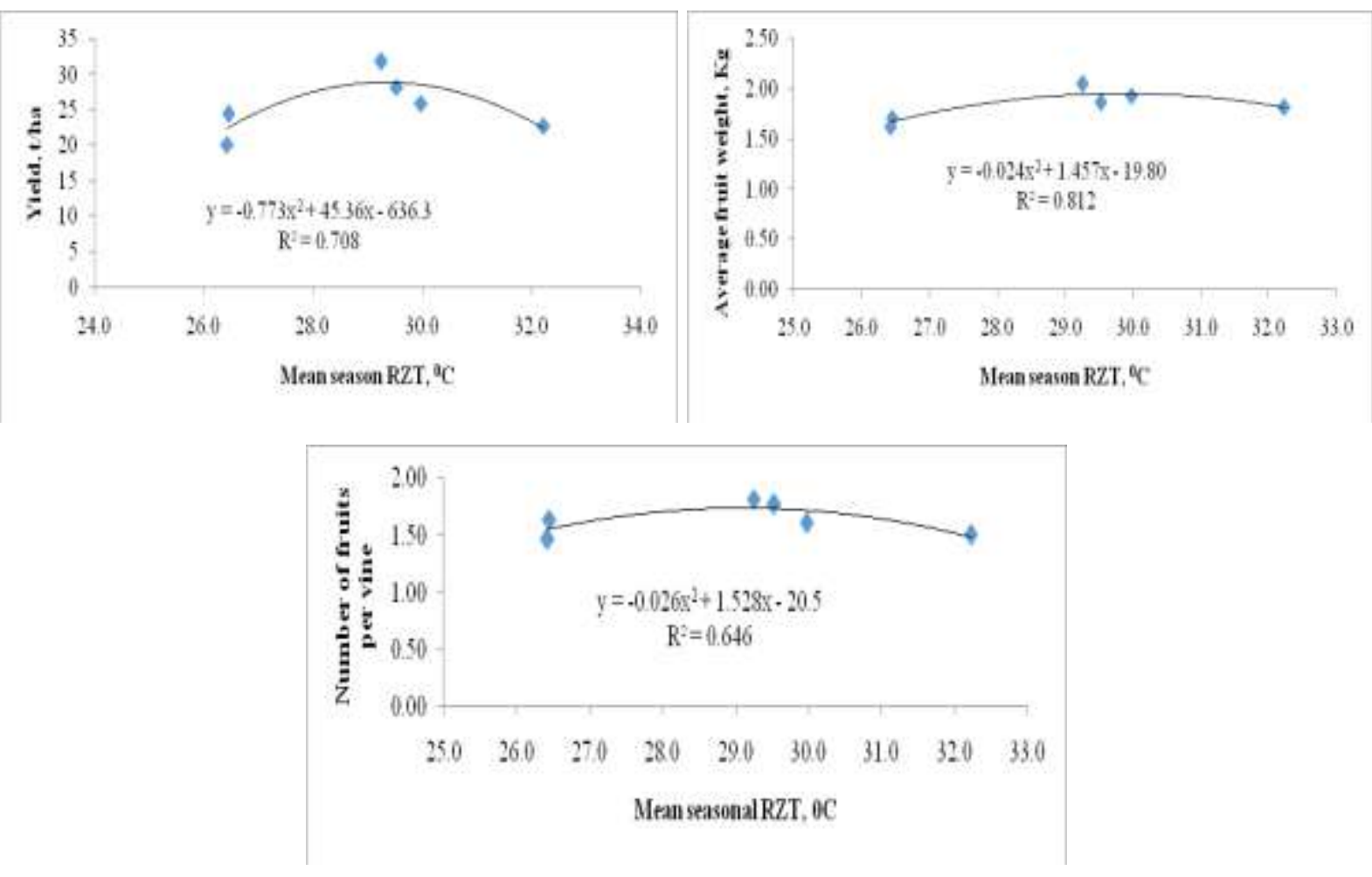


\section{Int.J.Curr.Microbiol.App.Sci (2019) 8(10): 2566-2576}

Fig.2 Relation of (a) mean afternoon and (b) mean morning root zone temperature with total yield, average weight of watermelon and number of fruit per vine
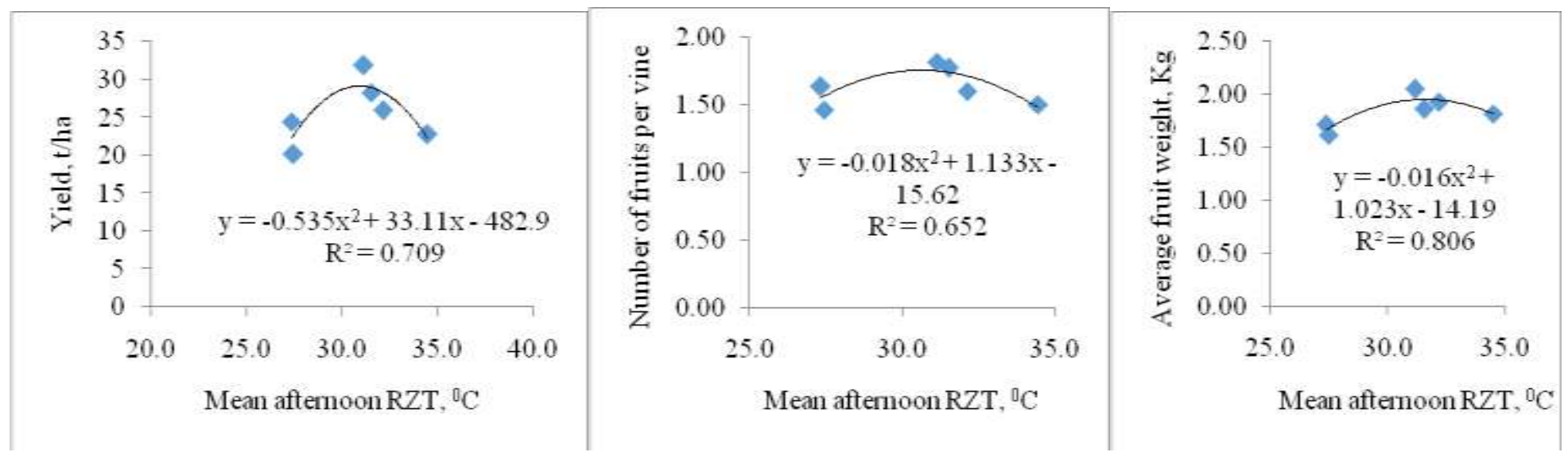

(a)
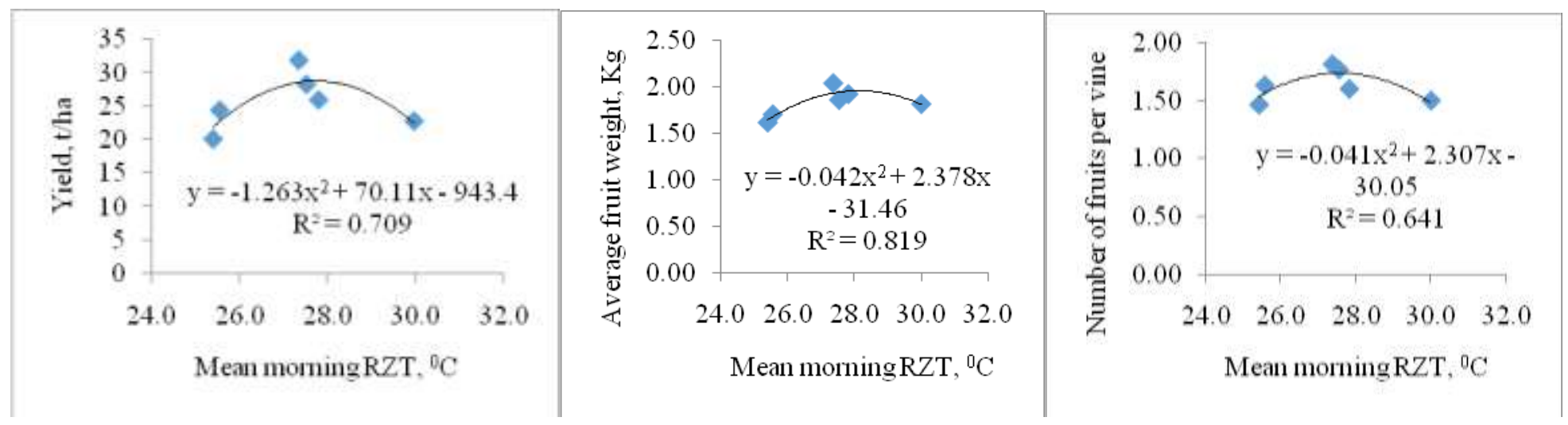

(b) 
Plants under black polyethylene mulch produced larger fruits and have higher fruit yield because of better plant growth due to favorable hydro-thermal regime of soil and complete weed free environment. These findings are in accordance with that of Parmar et al., (2013), who found that mulching material was significantly higher the fruit yield of watermelon. Romic et al., (2003) reported that, the highest watermelon yields were achieved on black film, which creates conditions favoring the growth and development by modifying the energy and water balance on the soil surface and thereby the yield of watermelon. Weather conditions in the study years had a significant influence on the yields of watermelon fruit. The significantly maximum yield $(26.22 \mathrm{t} / \mathrm{ha})$ of watermelon was obtained during growing season in 2015 as compared to growing season in 2016. The reason for the difference in yield was attributed to variation in weather conditions. The least favorable weather conditions in terms of irregular rainfall distribution and unbeneficial thermal conditions were recorded in the consecutive months of the growing season in 2016.

\section{Relationship of root zone temperature with yield attributing characters}

The data of watermelon fruit yield, fruit weight and number of fruits per vine fit a quadratic relationship with the mean morning RZT (root zone temperature), mean afternoon RZT and mean seasonal RZT (Fig. 1 and 2).

The fruit yield of control treatment was lower than other mulches treatment during both the years and did not fits in relationship, indicated that there may be more factors other than RZT which were responsible for lower yield of plants under control treatment. The optimum root zone temperatures were calculated by setting first derivative of equation equal to zero (Diaz-Perez and Batal, 2002). There was found significant positive correlation $\left(y=-0.7733 x^{2}+45.362 x-636.34\right.$; $\left.\mathrm{R}^{2}=0.7083 ; \mathrm{P}<0.01\right)$ between yield of watermelon and mean seasonal RZT. There was also found significant positive correlation $\left(\mathrm{y}=-0.0244 \mathrm{x}^{2}+1.4577 \mathrm{x}-19.801, \mathrm{R}^{2}=\right.$ 0.8127; $\mathrm{P}<0.01$ ) between mean fruit weight and average seasonal RZT. The number of fruits per vine also showed positive correlation with average seasonal RZT. Similarly, mean morning RZT and mean afternoon RZT shows the positive correlation with yield, average fruit weight and number of fruits per vine (Fig. 1 to 2). The optimum temperatures obtained in this experiment cannot be reliable, because they are based on relatively few data points [6 (three mulches $\mathrm{x}$ two trials)] and also it confined to season and variety of crop (Table 3). There is need to conduct several trials to obtained a valid relationship between RZT and growth attributing characters of watermelon.

In conclusions, the experiment conducted using different mulches and irrigation levels in commercial vegetable crop like watermelon that too under scarcity zone of Marathwada is the need of hour to save water without compromising yield and quality of produce. The results of this experiment revealed that polyethylene plastic mulch produced more vigorous plant and higher yield as compared to non-mulched treatment. This information can help growers to develop an irrigation strategy, selection of mulch type and is necessary for the future development of guidelines to help them improve production techniques of watermelon for their own profitability.

\section{Acknowledgement}

Authors are thankful to All India Coordinated Research Project on Irrigation Water Management, Vasantrao Naik Marathwada Krishi Vidyapeeth, Parbhani. 431402 (M.S.) 


\section{References}

Anonymous, 2012. Directorate of Economics and Statistics, Department of Agriculture and Cooperation.

Aniekwe, N. L. and Anike, N. T. 2015. Effects of different mulching materials and plant densities on the environment, growth and yield of cucumber. IOSR Journal of Agriculture and Veterinary Science, 8(11):64-72.

Awasthi, O. P., Singh, I. S. and Sharma, B. D. 2006. Effect of mulch on soilhydrothermal regimes, growth and fruit yield of brinjal under arid conditions. Indian J. Hort., 63(2): 192-194.

Ban, D., Žanić, K., Dumičić, G., Čuljak, T. G.and Ban, S. G. 2009. The type of polyethylene mulch impacts vegetative growth, yield, and aphid populations in watermelon production. Journal of Food, Agriculture \& Environment, 7 (3\&4): 543 - 550.

Bhanukar, M., Sindhu, S. S., Preeti and Prince. 2015. Effect of various mulches on growth, yield and quality of Kinnow. The Bioscan.10(3): 1379-1382.

Chawla, A. K., Singh, K. G. and Singh, A. 2009. Effect of mulch and drip irrigation on soil hydrothermal regime and potato yield (Solanum tuberosum L.). J. Res Punjab agric. Univ., 46(1\& 2): 68-71.

Deshmukh Y. K., Sinha, J., Sinha, G., and Verma, P. D. 2013. Effect of mulches and level of irrigation on soil temperature, soil moisture depletion and crop yield for bottle gourd. International Journal of Applied Engineering and Technology, 3(3): 2935.

Diaz-Perez, J. C. and Batal, K. D. 2002. Colored plastic film mulches affect tomato growth and yield via changes in root-zone temperature. J. Amer Soc Hortic Sci, 127:127-135.
Domber, R., Kamble, A. S., Channagoudar, R. F., Janwade, A. D. and Bhat, S. N. 2009. Effect of irrigation schedules and mulches on yield, soil temperature, water use and economic of sunflower (Helianthus annuus L.). Internat. J. agric. Sci., 5(2): $459-462$.

Ertek, A., Sensoy, S., Gedik, I. and Kucukyumuk, C. 2006. Irrigation scheduling based on pan evaporation values for cucumber (Cucumis sativus L.) grown under field conditions. Agricultural Water Management, 81: 159-172.

Gomez, K. A. and Gomez, A. A. 1984. Statistical procedures for agricultural research. John Wiley and Sons, Inc., New York.

Ham, J. M., Kluitenberg, G. J. and Lamont, W. J. 1993. Optical properties of plastic mulches affect the field temperature regime. J. Amer. Soc. Hortic Sci., 118(2): 188-193.

Ibarra-Jiménez, L., Zermeño-González, A., Munguía-López, J., Quezada-Martín, M. A. R. and De La Rosa-Ibarra, M. 2008. Photosynthesis, soil temperature and yield of cucumber as affected by colored plastic mulch. Acta Agriculturae Soil and Plant Science, 58: 372-378.

Khan, A. R., Rahman, A. and Singh, R. D. 2013. Influence of soil surface manipulation on soil temperature in relation to peanut production. Journal of Applied and Natural Science,5(1): 5357.

Kumar, R., Singh, A., Hooda, V., Singh, R. K. and Singh, M. 2015.Effect of organic manures, bio-fertilizer and mulching on growth and yield of Potato (Solanum Tuberosum L.). The Bioscan. 10(1): 403-406.

Lamont, W. J. 2005. Plastics: modifying the microclimate for the production of vegetable crops. HortTechnology, 15: 
477-481.

Mahadeen A. Y. 2014. Effect of polyethylene black plastic mulch on growth and yield of two summer vegetable crops under rain-fed conditions under semi-arid region conditions. American Journal of Agricultural and Biological Sciences, 9(2): 202-207.

Özmen, S., Kanber, R., Sarı, N. and Ünlü, M. 2015. The effects of deficit irrigation on nitrogen consumption, yield, and quality in drip irrigated grafted and ungrafted watermelon. Journal of Integrative Agriculture, 14(5): 966-976.

Parmar H. N., Polara, N. D. and Viradiya, R. R. 2013.Effect of Mulching Material on Growth, Yield and Quality of Watermelon (Citrullus lanatus Thunb) $C v$. Kiran. Universal Journal of Agricultural Research, 1(2): 30 - 37.

Romic, D., Borosic, J., Poljak, M. and Romic, M. 2003. Polyethylene Mulches and Drip Irrigation Increase Growth and Yield in Watermelon (Citrullus lanatus
L.). Europ.J. Hort. Sci., 68(4): 192198.

Schmidt, J. R. and Worthington, J. W. 1998.Modifying heat unit accumulation with contrasting colors of polyethylene mulch. HortScience, 33: 210-214.

Sharma, U. K. and Meshram, S. K. 2015. Evaluate the effect of mulches on soil temperature, soil moisture level and yield of capsicum (Capsicum annuum) under drip irrigation system. Internat. $J$. Agric. Engg., 8(1): 54-59.

Singh A. K. and Kamal, S. 2012.Effect of black plastic mulch on soil temperature and tomato yield in mid hills of Garhwal Himalayas. Journal of Horticulture and Forestry,4(4): 78-80.

Subrahmaniyan, K. and Ngouajio, M. 2012. Polyethylene and biodegradable mulches for agricultural applications: a review. Agron. Sustain. Dev.,32:501529.

\section{How to cite this article:}

Pawar, P.S., A.S. Kadale and Gadade, G.D. 2019. Effect of Various Mulches and Irrigation Levels on Root Zone Temperature, Growth and Fruit Yield of Watermelon (Citrullus lanatus T.) $c v$. Kiran. Int.J.Curr.Microbiol.App.Sci. 8(10): 2566-2576. doi: https://doi.org/10.20546/ijcmas.2019.810.297 